\title{
Research on Management of Housing Repair Project in Colleges and Universities from the Perspective of Fine Management
}

\author{
Yan Xiaofeng ${ }^{1, a}$ \\ ${ }^{1}$ College of Chinese Language and Culture, Jinan University, Guangzhou 510610, China \\ ayanxiaofeng@126.com
}

Keywords: housing repair project management; fine management; repair and purchase funds

\begin{abstract}
Since entering the new century, higher education has strengthened its connotation development under the background of enrollment expansion. The state implements many channels and forms of investment in higher education. Under the condition of straightening out the central and local school running systems, the central government has strengthened the investment in the teaching capital construction of the high-level key universities. From the beginning of this year, the central government has set up special funds to renovate housing and purchase instruments and equipment for dozens of subordinate colleges and universities, and to improve the running conditions of these key universities. The management of the housing repair project in colleges and universities has experienced a process of gradual exploration and perfection. In this process, some colleges and universities introduce the concept of fine management, optimize the management process, and effectively regulate and control, so as to explore some experiences in the fine management of housing repair in colleges and universities, and to form a fine management mode. Based on the background of the housing repair project in colleges and universities, this paper makes the fine and meticulous housing repair project.
\end{abstract}

\section{Research Background}

At the end of the 20th century, China's higher education experienced a profound change. Higher education has changed from elite education stage to popular education stage. At the same time, higher education has implemented major reforms in its management system and operational mechanism, that is, the reform of the school-running system and the implementation of management at the central and local levels. Secondly, colleges and universities should expand their enrollment and carry out the reform of socialized service. Thirdly, in order to guarantee the teaching quality of higher education and deepen the reform of education and teaching in colleges and universities, the reform of higher education oriented to the 21 century has carried out. In addition, other corresponding major reforms have implemented. Among them, "enrollment expansion" is a milestone in the history of the development of higher education, which deeply affects the basic trend of the development of higher education. Since the government adopted the policy of university enrollment expansion, the scale of higher education has expanded rapidly. In 2000, the total number of students in colleges and universities was only about 10, 000. However, since higher education is under the condition of elite education, Because of its small scale and small volume, its hardware condition meets the educational demand at that time under the low-level standard. Once the enrollment expansion and the single source of higher education funds depend on government investment, the contradiction between the conditions of running higher education and the large-scale development of higher education is particularly prominent.

After the students enter the school, the basic hardware guarantee conditions are the accommodation, the canteen, the classroom, the laboratory and so on. There are two basic solutions, namely, the new construction and the maintenance and renovation. After all, the new construction needs a large amount of funds and a certain period, so the colleges and universities are mainly on the old buildings at the same time. With the support of self-financing and government funds, every year, the cost of maintenance is few million and tens of millions more. Therefore, the maintenance 
work of the hardware facilities, especially the repair work of the house, has become extremely heavy in the work of the University. Regular work is a key task to ensure the normal operation of schools and promote their development. Therefore, it is a theoretical and practical work to study the management of housing repair project in colleges and universities. Therefore, this research is groundbreaking. From the point of view of reality, the research on the management of housing repair project in colleges and universities can guide the management work at the present stage. In particular, the introduction of the principle of fine management the research on the management of the building repair project in colleges and universities has the theoretical innovation and the guidance to the practical management work.

\section{The Implementation Process of Housing Repair Project Management in Colleges and Universities}

The management of the building repair project in colleges and universities is a comprehensive and extensive work, which not only includes complex and complicated construction management, but also requires the university to supervise the project quality and control the project cost. To grasp the progress of the project is the process of organizing, coordinating and managing the engineering quality, the use of funds and the construction schedule of the construction projects in colleges and universities. The management of the housing repair project in colleges and universities conducted according to the following procedures:

(1) The establishment of the housing maintenance project

(2) The demonstration of the project, Preliminary Design and budgetary estimate

(3) Project funding approval

(4) Organization Project implementation of detailed maintenance Program 1 Project Survey and Design, preparation of bid and bidding at the bottom of the bid

(5) Project implementation

(6) Project completion acceptance handling Project transfer

(7) Project settlement Audit Project completion Information File

(8) Project return visit and collect feedback Information.

\section{Brief Evaluation of Fine Management}

The concept and mode of fine management come from the modern production in the western developed countries in the century, especially in the modern industrial production with strong flow ability. Fine management has its unique advantages and special effects. The origin of fine management and its unique advantage in modern enterprise production lies in the fact that modern enterprise production is a highly mechanized, automated, information-based and process-oriented production model. A relatively closed production management system can formed within or within the enterprise. In this production management system, it is convenient to manage fine according to the three dimensions of quality, efficiency and benefit. Fine management meets benefits Maximization of goals. Because of the law of value, the pursuit of profit maximization is the goal of capitalism. To this end, we must work hard at input and output. Fine management takes three dimensions as the core and sets the accurate quality standard to calculate the minimum material and human resource input to produce the most qualified products at the same time, that is, the highest efficiency. In other words, scientific calculation and refinement in every link of production management Standard, save cost, improve efficiency. From the point of view of management, that is, through the precision supervision of quality, the accurate control of progress and the precise control of cost, we can achieve the production goal of the best product, the shortest time consuming and the lowest cost. Thus, fine management is a comprehensive, systematic management model. Comprehensive management is to integrate the concept of fine management into the whole management activities systematization is to apply refined management to each operation process. This is the core of fine management theory or practical management model. Fine management from the beginning in the industry the practice and exploration in production have achieved great success 
and quickly spread to the fields of modern industry and commerce, financial services and other fields, forming a concept and mode of enterprise management, which are widely recognized by the society. In a short time, a management theory of relative systems

\section{The Main Causes of the Problems in the Management of Housing Repair Project in Colleges and Universities}

\subsection{The constraints of traditional ideas}

We cannot keep up with the times and renew our ideas. Before the 1900s, there was a general understanding that the maintenance of college buildings could continue as long as the basic function could maintained without leakage and collapse. Repair, but also pay attention to solve leakage, break, the problem, but not pay attention to high standards of demand. Since entering the new century, the rapid development of science and technology, people's living standards continue to improve. That is not only to ensure that there is no leakage, but also to meet the higher requirements of teachers and students' teaching and research conditions, facilities modernization and intelligence. However, in the current maintenance management of colleges and universities, the maintenance units selected at the lowest price in order to save money.

\subsection{The constraint of current system}

The department in charge of running a school has not treated the building renovation project of its affiliated colleges and universities as a special normal investment. Before 1997, the school running system of colleges and universities was in a piecemeal form. All ministries and commissions of the State Council, provinces, municipalities, districts and related departments were running schools. Thus forms the relatively closed department school pattern. Departments with strong economic strength and provinces and municipalities put more money into their own schools, and the capital construction of the schools will safe guarded. On the contrary, if some schools receive very little investment, they can only maintain the basic operating expenses of running a school, and have no financial resources to invest in capital construction or maintenance. In addition, in the case of elite schools, the scale of universities is generally not very large, and the contradiction between conditional guarantee and school running needs relatively mild.

\subsection{Technical hindrance}

In addition to management concept and system, maintenance engineering in colleges and universities is subject to external conditions such as management level and technical level of domestic construction engineering enterprises. Because of the small amount of single project and the small amount of maintenance, the "regular army" is unwilling to do it, and the "miscellaneous army" is difficult to do well. In reality, there are many enterprises that link up with bidding; some enterprises with lower or no qualifications meet the bidding requirements because they do not meet the bidding requirements, and some bidding enterprises meet the bidding requirements by using the method of linking to higher-qualified enterprises. This brings great difficulty to the university's qualification examination for the bidding enterprises.

\section{Effectiveness of Meticulous Management of Repair Projects}

After years of exploration and practice, implementing fine management concept and implementing fine management mode, the fine management model has formed and achieved the expected effect. The main embodiment is to strictly control the project budget, save unnecessary expenses, and realize the cost saving two is basically completed according to the scheduled time schedule, guaranteed the project. The project is completed and accepted in time and put into use in time. It does not affect the normal school teaching, scientific research, and the order of life. It strongly supports the normal operation of the school three is the quality standard of the project, the quality of the maintenance of the project is all in conformity with the requirements, and the quality of some projects has been reached after a long time. Fourth, the integrity of the work of managers, 
construction workers, supervisors, auditors and other personnel has maintained, and no violation of discipline and law has taken place.

\section{Summary}

With the increasing investment of the Ministry of Finance's Central repair and purchase Fund in building maintenance and the purchase of large-scale instruments in key universities directly under the Ministry of Education, especially in the past two years, when the state is going to invest in education, it can foreseen. Therefore, how to implement the meticulous management of various engineering projects is a realistic subject in front of the relevant colleges and universities. Through the theoretical and empirical discussion on the meticulous management of maintenance engineering projects in colleges and universities, we can find that the meticulous management of these projects can found. It is necessary not only to follow the general and general standards and requirements of general construction project management, but also to achieve the core essence of construction project management. At the same time, to achieve a very short time limit, to ensure high quality maintenance and every penny spent in the appropriate place, it will be better than the general construction project management. That is to say, the overall maintenance project of the whole school must planned, approved, approved, tendered, prepared for cleaning up the project site, implemented, the whole project quality monitored. The project fine-tuned or changed, from the whole school's overall maintenance project planning, project establishment, budget, project examination and approval, tender invitation, project site cleaning preparation, project implementation Materials check and sign, project acceptance. The overall process, such as final expenses and pre-examination reduction, and follow-up visits at the later stage, should be guided by refined theories and concepts, so as to achieve "fine and accurate, accurate and accurate," so as to realize the three guarantees for the best quality of the project and for the timely completion of the project to be delivered. Ensure financial security and clean government. Like other building works, "the house is repaired, the man does not fall." Only by implementing fine management, can we ensure that every detail is of high quality, so that the whole project of high quality can completed on time only by implementing fine management, so that the tasks of each day can completed on time.

\section{References}

[1] Xiao Z c, renovation of Old buildings in Baining Colleges and Universities China Science and Technology Information

[2] Ecological significance of the reuse of Liu Wen's Old buildings

[3] A study on the Management system of University Infrastructure by Liu S h, F z, Wuhan Central China normal University Press, annual edition of Chen Z He's Handbook for Party a Representatives of Construction Units (Beijing China Construction Industry Press, 2009)

[4] Financial Management and Audit Supervision of institutions of higher Learning of the State Audit Office in Wuhan) Wuhan Central China normal University Press, 2005

[5] Wang Z, seeking details to determine success or failure (Beijing Xinhua Press, 2007)

[6] F W m, Wang Y m (in charge of Construction Project Management) Wuhan University of Technology Press, 2006

[7] Yuan Z g, Editor-in-Chief of Contemporary Pedagogy (Beijing Educational Science Press, 2004)

[8] W Jie's Editor-in-Chief of the practical Book of Modern Property Standard Management, Beijing Blue Sky Publishing House, 2004

[9] More than Wednesday, Chen C m, Lu M h, eds. Management-principles and methods, 4th edition, shanghai Fu d university press, 2001

[10] An introduction to Construction Engineering Supervision prepared by the National Supervision engineer training examination textbook. Beijing intellectual property Publishing House, 2008 